Copyright (C) 2014 by Academic Publishing House Researcher

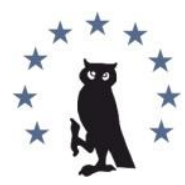

Published in the Russian Federation

European Researcher

Has been issued since 2010.

ISSN 2219-8229

E-ISSN 2224-0136

Vol. 85, No. 10-2, pp. 1835-1842, 2014

DOI: 10.13187/er.2014.85.1835

www.erjournal.ru

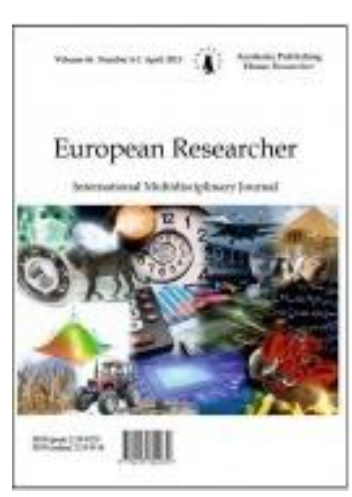

Economic sciences

Экономические науки

UDC 33

\title{
Human Trafficking and Commercialization of Surrogacy in India
}

\author{
Pyali Chatterjee
}

Disha Law College, Raipur, India

PhD, Assistant Professor

E-mail: pyali.chatterjee@gmail.com

\begin{abstract}
The Supreme Court of India, In Baby Manji Yamada versus Union of India \& Anr. [2008] INSC 1656, popularly known as Manji Case, declared that Commercial Surrogacy is legal in India. As we know that, India is a developing country and here, most of the peoples are very poor and illiterate. Recently, human trafficking was increase with an uncontrollable rate in the entire world. In addition, making Commercialization of Surrogacy legal had already give birth to a new form of trafficking. Where, illiterate women from poor section is trafficked to run the reproductive industry of the Surrogacy. As we know that the traffickers, they used to trafficked girls/women for prostitution but now after the legalization of Commercial Surrogacy, they will trafficked girl/women for the reproductive industry as a raw material. The Immoral Trafficking Prevention Act (ITPA), 1956 and Sections 366(A) and 372 of the Indian Penal Code, 1860 are the existing laws of India, which deals with human trafficking. However, none of these provisions contains any solution, to deal with this new serious issue of trafficking of women/girls for the purpose of Commercial Surrogacy in reproductive industries. These existing laws as well as the pending draft bill of Assisted Reproductive Technologies (ART) Regulation Bill, 2010 needs an amendment to check this crime against women once again to protect the rights and health of the women.

Keywords: Human Trafficking; Genetic parent; Commercial Surrogacy; Legalization; Prostitution.

\section{Indroduction}

The American Law Reports* defined the term "Surrogacy" in the following manner:

"... a contractual undertaking whereby the natural or surrogate mother, for a fee, agrees to conceive a child through artificial insemination with the sperm of the natural father, to bear and
\end{abstract}

\footnotetext{
* American Law Reports, ValIbidity and Construction of Surrogate Parenting Agreement, 77 A.L.R. 470. (1989)
} 
deliver the child to the natural father, and to terminate all of her parental rights subsequent to the child's".

According to the Black's Law Dictionary, "surrogacy means the process of carrying and delivering a child for another person"*.

Black Law Dictionary ${ }^{\dagger}$ divides surrogacy into two categories:-

1) Gestational Surrogacy - Here the genetic mother and father gives her eggs and sperms to another women (surrogate mother), which after fertilization is inserted into the womb of the surrogate mother and she carries the fetus till birth.

2) Traditional Surrogacy - Here the eggs belong to Surrogate mother and by artificial insemination, fertilization took place. In addition, she will carry the fetus until birth the of child.

We all know that, a family is complete when there is a child. A child is a gift of god, upon whose arrival the entire family celebrates with joy. However, not all couple in the world is so lucky to have their own child. So, what they can do to have their own Child? The answer is Surrogacy, a new modern technique i.e. Assisted Reproductive Technique of reproduction for having one's own baby. In nonprofessional language surrogacy is a process by which one can carry the baby of others until the birth of the baby with the help of modern medical facilities. Surrogacy can be of two types as the types given by Black Law Dictionary:-

1) Traditional Surrogacy: - Its process by which the sperm of the donor or the sperm of the father is artificially inseminated in the women. By this process, the women get pregnant and she carries the fetus for 9 months. Here in this process, the woman is the biological mother of the child because it is her egg, which was fertilize with the sperm of the donor or the sperm of the father.

2) Gestational Surrogacy: - Here in this case, the fertilization is done through In Vitro Fertilization in short through IVF. In this process, the egg and sperm of the intended parents is collected for artificial fertilization i.e. through IVF. Once the embryo is formed, then it is transfer to the surrogate mother by the use of Assisted Reproductive Technique. The surrogates' mother carries the baby until the birth of the child. Here, in this case the surrogate's mother is not the biological mother of the child because the egg that is use for the fertilization does not belong to her.

Now a day most of the couple who are medically unfit and want to have their own baby goes for Gestational Surrogacy, because the baby here will not be genetically attached to the surrogate's mother. As, both the egg and sperm used for the fertilization belongs to the biological parents or one of the gametes may belong to the intended parents and the other gametes from the donor but not belonging to Surrogates mother. Moreover, Countries like India; Ukarine allows Gestational Surrogacy on Commercial basis and are legal there. Some countries like Netherlands, France, and Canada, Australia they do not allow Commercial Surrogacy and its illegal there.

Commercial Surrogacy is a written agreement between the Genetic parents and the Surrogates mother. Dealing with the terms and conditions to be applied during the whole course of pregnancy till delivery of the baby.

\section{Commercial surrogacy in India}

In 1978 , October 3 , India become the world $2^{\text {nd }}$ nation to use IVF( in vitro fertilization) procedure to give birth to a baby girl named Kanupriya alias Durga at Calcutta, that also after the birth of the first baby boy through IVF named Louise Joy Brown born in Great Britain in the year 1978 , July $25 .^{*}$

It was after the use of IVF procedure by the fertility Clinic, Assisted Reproductive Technologies become popular among couples who are medically unfit for giving birth of their child.

In India the first child born through gestation was at Dr. Nayna Patel's Akanshka Fertility Clinic in Anand, Gujarat in 2004, where Rhadha Patel aged 47 years, became surrogates mother for her UK based daughter. After that case, the Dr. Nayna Patel's Akanshka Fertility Clinic was highlight in media there by attracting numbers of foreign Couples.

\footnotetext{
${ }^{*}$ Law Commission of India in Report No-228, Need For Legislation To Regulate Assisted Reproductive Technology Clinics As Well As Rights And Obligations Of Parties To A Surrogacy, August 5, 2009 http://lawcommissionofindia.nic.in/reports/report228.pdf

${ }^{\dagger}$ Ibid.

${ }^{*}$ Ibid.
} 
It was after the case of Baby Manji Yamada versus Union of India \& Anr. [2008] INSC 1656*, where by Supreme Court in its judgment mentioned that Commercial Surrogacy is legal in India and asked the Legislature to pass a Law to govern the Surrogacy. According to that, Legislature has prepared a bill called Assisted Reproductive Technologies (ART) REGULATION Draft Bill 2010, which is still pending for its approval.

It was mentioned in the Report No-228 of Law Commission of India ${ }^{\dagger}$, that the price fixed for the Commercial Surrogacy Agreement, between the Intended parents and the surrogate mothers in India, is near about $\$ 25,000-\$ 30,000$ that is around $1 / 3$ from the other countries ${ }^{\ddagger}$.

Only because of this low cost, Modern medical facility and with no strict laws to regulate this Reproductive Industries and of course because of easy availability of surrogate mother India becomes the favorite destination for the foreign couples. Thus, the income of the ART Clinics is increasing. India becomes the favorite destination for Commercial Surrogacy for foreign couples where Commercial Surrogacy is not legal.

\section{Commercial surrogacy and human trafficking}

In a recent study done by the National Rapporteour On Trafficking In Human Beings of Dutch $^{\S}$, and also the report submitted by the same, raised a question about the Commercial Surrogacy, that whether the women for commercial surrogacy were coming voluntarily or forcefully to become a Surrogates mother?

"Jyotsna Gupta, a senior lecturer in gender studies and diversity at the University of Utrecht, argues that Indian surrogate mothers are usually under enormous pressure from their husband and family"**.

In countries, where most of the population belongs to poor society, rights of women's from that society were infringed and violated by the intermediary and the clinics for the money which was agreed to be paid to the Surrogate mother for the purpose of Commercial Surrogacy. Because most of the money which she is about to receive from this surrogacy agreement were taken by the Reproductive clinics and the broker.

In fact, we can say that, For Commercial Surrogacy, the illiterate surrogates mother from the poor background are in danger. Because brokers and the clinics exploit their rights and even sometimes they are force to become the surrogate mother or egg donor.

Dr. Roel Schats ${ }^{\dagger \dagger}$, chief medical officer of the IVF centre of the VU Medical Centre, argued against Commercial Surrogacy, "It is a form of modern slavery to use an Indian woman as a breeding machine without the benefit of any form of care". Moreover, slavery system is the violation human rights.

It was submitted in the report ${ }^{\ddagger}$ that in case of Commercial Surrogacy, if a woman was forced, Coerced and exploited to become Surrogates mother in that case it will be considered as a crime. Thereby, it will fall under trafficking.

There is a huge demand of Surrogate mothers in the Medical Clinics or in the Reproductive Industries, by the needy couples for the Gestational Surrogacy as well as for Commercial Surrogacy. As the demand of surrogates mother and egg donor is too high in the current scenario, for the Reproductive Industries, so to meet the demand, supply of the surrogate's mother and the egg donor is required in the same ratio. Thus, it will increase the trafficking of women in the global

\footnotetext{
* Kari Points, Commercial Surrogacy And Fertility Tourism In India The Case Of Baby Manji, INSTITUTION IN CRISIS, https://web.duke.edu/kenanethics/CaseStudies/BabyManji.pdf

+ Law Commission of India in Report No-228, Need For Legislation To Regulate Assisted Reproductive Technology Clinics As Well As Rights And Obligations Of Parties To A Surrogacy, August 5, 2009

http://lawcommissionofindia.nic.in/reports/report228.pdf

* Ibid. at11

§National Rapporteur on Trafficking in Human Beings, Human trafficking for the purpose of the removal of organs and forced commercial surrogacy, THE HAGUE: BNRM, 2012, at.18

http://www.dutchrapporteur.nl/reports/organ-removal-forced-commercial-surrogacy/

${ }^{* * *}$ Ibid., at 19

${ }^{+\dagger}$ Ibid. at 20

${ }^{*}$ National Rapporteur on Trafficking in Human Beings, Human trafficking for the purpose of the removal of organs and forced commercial surrogacy, THE HAGUE: BNRM, 2012

http://www.dutchrapporteur.nl/reports/organ-removal-forced-commercial-surrogacy/
} 
black market of Reproductive trade to meet the demand of Surrogates mother and egg donor as well.

In a Article published by Prof. Rita Biswas* in Human Trafficking - A Burning Problem In India , mentioned that near about 80\% of the human trafficking used to be done for sexual exploitation and the remaining portion for forced slavery and India is considered to be the highest crime rate ratio in trafficking in Asia. According to the definition of the United Nations, "trafficking is any activity leading to recruitment, transportation, harboring or receipt of persons, by means of threat or use of force or a position of vulnerability"

So, if a woman is forced to become Surrogates mother or forced to donate her eggs in that case it will be a crime and will fall under human trafficking as per the definitions of United Nations. The report which was submitted by National reporter ${ }^{\ddagger}$ said that, if a woman is forced to become a Surrogates mother then in that case it will comes under trafficking and it will be a crime. We can consider the reports submitted by National Reporter for the amendment of our existing trafficking laws as well as for making new laws.

Ranjana Kumari,\$ Director of Center for Social Research said that, in most of the cases relating to Commercial Surrogacy, it was found that, the surrogate mothers were exploited.

According to Akanksha Patel ${ }^{* *}$, "Legislation should be there so that this wonderful procedure can be supervised and it is being done by the right people for the right people".

Due to absence of law relating to Commercial Surrogacy in India, in case of death of surrogate mother or miscarriage due to any complication, the hospital authority and the genetic parent are not liable. In India, no one is liable for the misery of the Surrogate Mother.

The UNODC Model Law against Trafficking in Persons is develop by the United Nations Office on Drugs and Crime (UNODC) to assist States in implementing the provisions contained in the Protocol to Prevent, Suppress and Punish Trafficking in Persons, Especially Women and Children, supplementing that Convention. ${ }^{\dagger+}$ And here they had suggested to include "the use of women as surrogate mother ${ }^{\ddagger \neq}$ " under exploitation. Moreover, we know that exploitation of human beings come under violation of Human Rights.

Even it was found that, in case of any complications during delivery, the Doctors tried to save the life of the unborn baby first and after that the life of the mother. Since, the fixed money was for the unborn baby and not for the mother. Only because of this reasons the life of the unborn child have first priority over mother's life.

\section{Cases of human trafficking and views for commercial surrogacy}

1. In absence of surrogacy law, women in India are subject to many sufferings both mentally and physically. And there was a case in India, where a girl from the orphanage of Haryana, sold out for two times within $3 \mathrm{yrs} .{ }^{\S}$.

2. Another incident of human trafficking in 2011 was report, where 14-15 Vietnamese women were rescue from Thailand and they were trafficked and forced to become Surrogate mother for Commercial Surrogacy by a company named BABY 101.*

\footnotetext{
* Rita Biswas, Human Trafficking - A Burning Problem In India, 2(4) ONLINE JOURNAL EPISTEME, (March, 2014), http://www.bharatcollege.in/PDFs/human-trafficking---1394774411.pdf

${ }^{\dagger}$ Ibid.

${ }^{\ddagger}$ National Rapporteur on Trafficking in Human Beings, Human trafficking for the purpose of the removal of organs and forced commercial surrogacy, THE HAGUE: BNRM, 2012

http://www.dutchrapporteur.nl/reports/organ-removal-forced-commercial-surrogacy/

$\S$ Nita Bhalla , Manshi Thapliya, India seeks to regulate its booming' rent-a-womb' industry, (Mon Sep 30, 2013, 1:01 pm) REUTERS, http://www.reuters.com/article/2013/09/30/us-india-surrogates-

IbidUSBRE98To7F20130930

${ }^{* * *}$ Ibid.

${ }^{+\dagger}$ United Nations Office on Drugs and Crime, Model Law Against Trafficking in Persons, at. 1 http:// www unodc.org/documents/human-trafficking/UNODC_Model_Law_on_Trafficking_in_Persons.pdf

\# Ibid. Sec.2(f) at 28

$\S \S$ Vrinda Marwah, Commercial Surrogacy In India, GENEWATCH, http://www.council

forresponsiblegenetics.org/GeneWatch/GeneWatchPage.aspx?pageIbid=350\&archive=yes
} 
3. In the year 2009, another case of Commercial Surrogacy involved with trafficking known as Romanian Scandal ${ }^{\dagger}$ was exposed. In that case, eggs from the minor girls were trafficked by the Israeli Doctors in one of the clinic named SABYC Clinic in Romania. Even a girl of 16 years was rescue in a serious condition, left after the eggs removal procedure.

3. Even in the article published by Debesh Banerjee, ${ }^{\ddagger}$ he mentioned that, while making the famous documentary movie, filmmaker Ishani K Dutta, first did research for her documentary film "Womb on rent". The movie was based on Surrogacy. While doing her research she found that, even though it is in the ICMR guidelines that, a girl below 18 years could not donate her eggs. However, in reality it is opposite. Because while doing research for her film, she found that girls below 18 years were also donating eggs. In addition, a girl of 17 years, died in Mumbai after the two days of eggs removing procedures. She expressed her fear that by this way, girls after attaining her puberty will become a machine for printing money for others. She also found that, the conditions of surrogate mothers in India are not good and they were exploited by the moneymaking fertility Clinics.

4. Again, in an article published by Kathleen Sloan§, he said that, In Surrogacy process, surrogates mother acts like a Commercial Industry and the product of this Industry, is the baby born through this process. Women from the poor section were exploits, and there health is on risk throughout this process. The European Parliament in the year 2011 declared that the process of surrogacy violates the human rights of the women.

5. In India, a 26 years woman named Yuma Sherpa from Delhi, died during the egg removal procedures and a 17 years Girl named Sushma Pandey from Mumbai, died after two days of egg removal procedures. Because of the absence of law and guidelines regarding how many eggs can be removed from the body at a time and the dosage of injection Gonadotropin that is used for producing multiple of eggs has increased a great concern for the doctors, lawyers and Human rights activist in respect of the health and life of the women.**

6. Recently, the Thailand Military Government ${ }^{\dagger \dagger}$, after the case of BABY GAMMY, has given approval for a drafted bill by which Commercial Surrogacy in Thailand will amount to be a criminal offence and there by making it banned. Because of the problems related to Commercial Surrogacy.

\section{Violation of article 19, 21 and 23 of indian costituton}

According to Article 16.1 of the Universal Declaration of Human Rights 1948, "men and women of full age without any limitation due to race, nationality or religion have the right to marry and found a family" ". In India also, the reproductive right is a basic human right given under Article 21 of the Constitution of India. The Andhra Pradesh High Court in B. K. Parthasarthi v. Government of Andhra Pradesh, AIR 2000 A. P. 156, ruled that reproductive right is a human right and its comes under right to privacy and also they agreed with the decision of the US Supreme Court in Jack T. Skinner v. State of Oklahoma, 316 US 535 which characterized the right to reproduce as "one of the basic civil rights of man $\$$ ". Nevertheless, my question is Does this right allow exploitation of the basic human rights of other?

\footnotetext{
* Weena Kowitjwani, Thai Organization Involved in Trafficking in Vietnamese Surrogate Mothers Uncovered, ASIANEWS.IT (Mar. 2, 2011) http://www.asianews.it/news-en/ Thai-organisation-involved-intrafficking-in-Vietnamese-surrogate-mothers-uncovered-20916.html

${ }^{\dagger}$ Hedva Eyal, Reproductive Trafficking ,GENEWATCH

http://www.councilforresponsiblegenetics.org/genewatch/GeneWatchPage.aspx?pageIbid=313

${ }^{\ddagger}$ Debesh Banerjee, A Surrogate Story, THE INDIAN EXPRESS, Mar. 21, 2014

http://www.geneticsandsociety.org/article.php?Ibid=7631

$\S$ Kathleen Sloan, Inconvenient Truths about Commercial Surrogacy, TWIN CITIES, Apr.1, 2014, http://www.geneticsandsociety.org/article.php?Ibid=7663

${ }^{* * *}$ Womens eNews, Donor Deaths In India Hightlight Surrogacy Perils, THOMSON REUTERS

FOUNDATION, (Jun. 16 2014, 09:16 GMT), http://www.trust.org/item/20140617101347-iuox4/

${ }^{+\dagger}$ Reuters in Bangkok, Thailand To Band Commercial Surrogacy In Wake Of Gammy Scandal, THEGURDIAN (Aug. 13, 2014, 20.01 BST),

http://www.theguardian.com/lifeandstyle/2014/aug/13/thailand-ban-surrogacy-gammy

*¥ The Universal Declaration of Human Rights, http://www.un.org/en/documents/udhr/index.shtml\#a16

$\S \S$ Law Commission of India in Report No-228, Need For Legislation To Regulate Assisted Reproductive

Technology Clinics As Well As Rights And Obligations Of Parties To A Surrogacy, Aug. 5, 2009, at 12
} 
Because, from the above discussion, we have found that Commercial Surrogacy is a gift of Science and Technology to the infertile or medically unfit couples to have there own baby. Moreover, on the other hand it has a very strong negative impact in the Society as we can found that how the Surrogate mother were treated in India. There is a great violation of women rights under Article 21, which grants "No person shall be deprived of his life or personal liberty except according to procedure established by law"*, Article 19(1) (a) which grants "Freedom of Speech and Expression" " of the Constitution of India and Article 23 which grants "Prohibition of traffic in human beings and forced labour" work also. The society where we are staying in India is a male dominating society. Moreover, women had no rights to do even what they wanted to do in there life. In addition, for this reason the women from Poor Indian society were in great risk. Poor women were forced by there husband for the money paid, to become surrogates mother and sometimes for the donation of there eggs. This is great violation of the Article 21 and 19(1) (a). Even the hospital authority they do not allow the surrogates mother to stay with there family during the pregnancy and they had to stay in the Hostels or the accommodation provided by the Reproductive Clinics under there observations. By this also, there right get violated under Article 21. In addition, they had no right to express there feelings which is again Violation of Article 19(1) (a). As they were, force to become surrogate mother, so there rights were, violated under Article 23 also. Even if there is any complication during the delivery of child, the life of the unborn child used to give more importance by the Reproductive Clinic and not the mother life, which is again a violation of the Reproductive Rights of Article 21.

\section{Costitutional right is to ensure freedom and not exploitation Sugessition}

The following are the suggestion by which we can control the trafficking related to commercial Surrogacy in India:

1) There is a need of Strong Uniform International Law to control the trafficking related to Commercial Surrogacy in the entire world to protect the rights, life and privilege of women. immediately.

2) The pending Assisted Reproductive Technologies (ART) Bill, 2008 has to pass

3) Unmarried woman should not be allowed to become surrogate mother as well as egg donor.

4) Special Act and Amendments is needed in the existing Immoral Trafficking Prevention Act (ITPA), 1956 and in the Indian Penal Code, 1860 for trafficking in Surrogacy.

5) All the surrogates mother must be provided with compulsory life insurance policy, failing of which the clinics or the genetic parents will be punished accordingly.

6) Before signing of the surrogacy agreement, information regarding the reproduction process through surrogacy should be disclosed in full entirety by the Clinics and doctors responsible for the same. first.

7) In case of any complications, the health of the surrogate mother should be considered

8) Every reproductive clinic must have a team of counselors capable of providing a good counseling to the surrogate mother and to check whether she is coming willingly or not for surrogacy and the person, forcing her to surrogacy must be punished.

9) Government should motivate the couples to go for adoption.

10) Only those couple be allowed for Commercial Surrogacy who is medically unfit to have there own child and not those who already have a child of their own.

11) The hospital authority in case of Commercial Surrogacy process should not entertain any intermediary.

12) Amount for Commercial Surrogacy should be fixed by the Government, which is to be paid to the surrogate mother by the intended parents along with the terms and conditions in the surrogacy agreement.

* O.P Rai, The Constitution of India, 30, (Orient Publishing Company, $2^{\text {nd }}$ ed, 2014)

† Ibid. 31

* Ibid. 39 
13) Uniform law and guideline should be there across the World regarding the dosage of Gonadotropin injection or any synthetic hormone, which is used in the process of egg removal. And also the number of human eggs and its limits for its donating and the time interval between the first and second donation.

14) According to section 26(8) of ART Bill, 2010, a woman can donate her eggs for not more then six times in her entire life and the interval between each donation should be three months. However, nothing is mention about the number of eggs that can be removed at a time.

15) General Awareness is to be spread with the help of the media regarding the risk of the process of human eggs donation.

16) Only a relative, friend or known person should be allowed to act as surrogate mother or egg donor for Commercial Surrogacy in order to check human trafficking.

17) We can consider the reports submitted by National Reporter* for the amendment of our existing trafficking laws as well for making new laws.

18) Forced Surrogacy should also be considers in trafficking and the person who does so should be punished accordingly.

19) Only those couple be allowed for Commercial Surrogacy who is medically unfit and not those who already have a child of their own.

20) In India, only the top few Hospitals be allowed to practice Commercial Surrogacy and not all the Clinics. So that, the Government should be able for periodical inspection of the hospitals to find out that whether the surrogate mothers were willingly coming or they are coming by forced or by trafficked. If the number of hospitals will be less then it will be easy for the Government to check the Hospitals also.

21) To prevent the exploitation of surrogate's mother in the hand of medical clinics and brokers, the Government should fix the amount for the Surrogacy Agreement, which the Genetic/intended Couples directly pay to the surrogate's mother, excluding the medical expenses.

22) General Awareness is to be spread with the help of the media regarding the risk of the process of human eggs donation as well as the risk of the life of the Surrogates mothers and its future side effects.

\section{Conclusion}

From the above discussion, we have found that Commercial Surrogacy is a gift of Medical Science and Technology to the infertile or medically unfit couples to have their own baby. Moreover, on the other hand it has a very strong negative impact in the Society, when we consider about the health, life and rights of the poor Surrogates mother. In the absence of Uniform International Law to regulate the Reproductive Industries, the black market of organ trafficking for the supply of Surrogate mothers and eggs for Commercial Surrogacy, the Industries is flourishing day by day with the increase of trafficking of women and minor girl in Indian market as well as in the International market. To deal with the present scenario, uniform International Law is to be passed to control the trafficking in the places like India. Last but not the least, in order to conclude the above discussion I would like to suggest that meaning full and stringent laws should be framed at both National and International Level and at the same time it should be strictly implemented by the state ensuring the protection of rights of women in the society, there by achieving the object of an ideal political state.

\section{References:}

1. Using a Surrogate Mother: What You Need to Know. WebMD, (July. 16 ${ }^{\text {th }}$, 2014, 11.30 am) http://www.webmd.com/infertility-and-reproduction/guide/using-surrogate-mother

2. National Rapporteur on Trafficking in Human Beings (2012). Human trafficking for the purpose of the removal of organs and forced commercial surrogacy. The Hague: BNRM, pg.18

3. Rita Biswas, HUMAN TRAFFICKING - A BURNING PROBLEM IN INDIA, 2 BCC-ISSN 2278-8794, (March,2014)

\footnotetext{
${ }^{*}$ National Rapporteur on Trafficking in Human Beings, Human trafficking for the purpose of the removal of organs and forced commercial surrogacy, THE HAGUE: BNRM, 2012

http://www.dutchrapporteur.nl/reports/organ-removal-forced-commercial-surrogacy/
} 
4. Nita Bhalla, Manshi Thapliya, India seeks to regulate its booming' rent-a-womb' industry, (Mon Sep 30, 2013, 1:01 pm) Reuters, http://www.reuters.com/ article/2013 /09/30/ us-india-surrogates-idUSBRE98To7F20130930, last visited July 19, 2014

5. Weena Kowitjwani, Thai Organization Involved in Trafficking in Vietnamese Surrogate Mothers Uncovered, ASIANEWS.IT (Mar. 2, 2011), http://www.asianews.it/news-en/Thaiorganisation-involved-in-trafficking-in-Vietnamese-surrogate-mothers-uncovered-20916.html, last visited July 19, 2014

6. United Nations Office on Drugs and Crime, Model Law Against Trafficking in Persons, http://www.unodc.org/documents/human-trafficking/UNODC_Model_Law_on_Trafficking_in _Persons.pdf

7. Yasmine Ergas, Babies Without Borders: Human rights, Human dignity, and the regulation of International Commercial Surrogacy, 27,Emory International Law Review,117

8. Thanh-Dam Truong, Human Trafficking, Globalisation and Transnational, Feminist Responses, 579 ISSN 0921-0210, Januaray 2014

9. CT Nilesh, Rent-a-womb, a thriving business but a moral and legal conundrum, AsiaNews.it, December 21, 2009, http://www.asianews.it/news-en/Rent-a-womb,-a-thrivingbusiness-but-a-moral-and-legal-conundrum-17180.html, last visited July 19, 2014

10. Hedva Eyal, Reproductive Trafficking, GENEWATCH,

http://www.councilforresponsiblegenetics.org/genewatch/GeneWatchPage.aspx?pageId=31 3, last visited July 19, 2014

11. Vrinda Marwah, Commercial Surrogacy In India, GENEWATCH, http://www. councilforresponsiblegenetics.org/GeneWatch/GeneWatchPage.aspx?pageId=350\&archive=yes,las t visit July 19, 2014

12. Holly Williams, Are Indian surrogacy programs exploiting impoverished women?, CBS NEWS, April 11, 2013, 7:58 PM, http://www.cbsnews.com/news/are-indian-surrogacy-programsexploiting-impoverished-women/, Lastvisited July 23, 2014

13. Smith Chandra, Surrogacy and India, NALSAR University of Law, February 16, 2011, http://papers.ssrn.com/sol3/papers.cfm?abstract_id=1762401, Lastvisited July 25, 2014

14.Alison Bailey, Reconceiving Surrogacy: Toward a Reproductive Justice Account of Surrogacy Work in India, http://papers.ssrn.com/sol3/papers.cfm? abstract_id =1518026 \&rec= $1 \&$ srcabs $=997923 \&$ alg $=1 \&$ pos $=4$, July 25, 2014

15. Deborah Conlon, "No Pain, No Gain": Outsourcing Surrogacy In India, Development Perspectives, May 29, 2014, http://www.developmentperspectives.ie/no-pain-no-gainoutsourcing-surrogacy-in-india/, Last visited, July 23, 2014

16. Debesh Banerjee, A Surrogate Story, The Indian Express, March 21, 2014, http://www.geneticsandsociety.org/article.php?id=7631, last visited July 26, 2014

17. Kathleen Sloan, Inconvenient Truths about Commercial Surrogacy, Twin Cities, April 1,2014, http://www.geneticsandsociety.org/article.php?id=7663, July 26, 2014

18. Womens eNews, Donor Deaths In India Hightlight Surrogacy Perils, Thomson Reuters Foundation, Mon, Jun 16 2014, o9:16 GMT, http://www.trust.org/item/ 20140617101347-iu0x4/, last visited July 28, 2014 